\title{
NAÇ̃̃O E REVOLUÇÃO - GARRETT, ANTERO E EDUARDO LOURENÇO NA BALANÇA DA MODERNIDADE
}

\author{
Silvio Cesar dos Santos ALVES \\ (Universidade Estadual de Londrina) \\ silviohaiti@hotmail.com
}

\begin{abstract}
Resumo: O presente trabalho tem como objetivo confrontar, à luz da História das Ideias, as diferentes posições assumidas por Almeida Garrett (1799-1854), Antero de Quental (1842-1891) e Eduardo Lourenço (1923) relativamente aos valores ligados às noções de "Pátria", "Nação" e "Revolução" em suas respectivas épocas. Com esse propósito, abordaremos textos como 0 Chronista (1827), Portugal na balança da Europa (1830), o drama Frei Luis de Sousa (1843) e o romance Viagens na Minha Terra (1846), de Garrett; o artigo Portugal perante a Revolução de Espanha (1868), a conferência Causas da decadência dos povos peninsulares nos últimos três séculos (1871) e alguma poesia de Antero; bem como a obra $O$ labirinto da Saudade - mais especificamente o ensaio intitulado "Psicanálise mítica do destino português" (1978) -, de Eduardo Lourenço.
\end{abstract}

Palavras-chave: Nação. Revolução. Modernidade.

\section{NATION AND REVOLUTION - \\ GARRETT, ANTERO AND EDUARDO LOURENÇO IN THE SCALE OF MODERNITY}

\begin{abstract}
This work aims at confronting, in the light of the History of Ideas, the different positions assumed by Almeida Garrett (1799-1854), Antero de Quental (1842-1891) and Eduardo Lourenço (1923) in regard to the values linked to notions of "Fatherland", "Nation" and "Revolution" in their respective eras. For this purpose, the discussion centers on texts such as O Chronista (1827), Portugal na balança da Europa (1830), the drama Freis Luis de Sousa (1843) and the novel Viagens na Minha Terra (1846), by Garrett; the essay Portugal perante a Revolução de Espanha (1868), the conference Causas da decadência dos povos peninsulares nos últimos três séculos (1871) and some of Antero's poetry. This paper will deal with some aspects of the work $O$ Labirinto da Saudade - more specifically the essay titled "Psicanálise mítica do destino português" (1978) -, by Eduardo Lourenço.
\end{abstract}

Keywords: Nation. Revolution. Modernity. 
No texto prefacial escrito para O Labirinto Saudade, em 2000, Eduardo Lourenço faz a seguinte constatação: "o país que há vinte e dois anos podia justificar um livro como O Labirinto já não existe" (LOURENÇO, 2010, p. 12). A essa altura, Lourenço já havia desenvolvido vários e importantes estudos acerca da problemática europeia, ou da Europa Desencantada - título de um livro publicado por ele primeiramente em 1999. O prefácio do Labirinto, escrito há 14 anos, deve ser inserido nesse contexto. Nele, o autor constata a "avassaladora dissolução das entidades clássicas a que chamávamos nações", assim como a multiplicação da "reivindicação de microidentidades virulentas ou superidentidades" - traços contraditórios de "um mundo ao mesmo tempo globalizante e intimamente fragmentado" (LOURENÇO, 2010, p. 13). O objeto de seu radical exame de consciência, antes restrito a Portugal enquanto Nação, agora tinha como objeto a Europa como um todo, numa perspectiva europeísta. Cogitando a possibilidade de interpretar a história dos povos como a de um ser, o autor afirma:

\begin{abstract}
Portugal nunca sofreu metamorfose comparável à dos últimos vinte anos. Não foi apenas uma mudança exterior, uma dilatação comparável à do tempo em que se tornou país das Descobertas, mas uma alteração ontológica, se isto se aplica a um povo. Estamos tão dentro dela que a não podemos pensar. Que mais não fosse, caracteriza-a o facto de tal metamorfose não ser obra sua, ou eminentemente sua, como o foi noutras épocas. Trata-se de um fenômeno mais vasto, o fim da civilização europeia sob paradigma cristão e iluminista, se é lícito associar estas duas matrizes da milenária e agora defunta Europa (LOURENÇO, 2010, p. 13)
\end{abstract}

$\mathrm{Na}$ página anterior ao texto supracitado, Eduardo Lourenço já havia afirmado que essa mudança não dizia respeito somente a Portugal, sentenciando: "mudamos, literalmente falando, e sem quase nos darmos conta disso, de mundo. Mudámos porque o mundo conheceu uma metamorfose sem precedentes, não apenas exterior, mas de fundo. Já não habitamos o mesmo planeta" (LOURENÇO, 2010, p. 12-13).

A partir do que foi exposto até aqui, cremos ser inevitável fugir a algumas indagações: aquilo que, segundo Eduardo Lourenço, tornava sua obra desatualizada era o método da investigação proposta ou a aplicação dessa investigação de forma restrita a Portugal? No entender de Lourenço, o mundo restringir-se-ia à Europa? O fim do paradigma cristão e iluminista poderia mesmo, sem complicações, ser comparado ao fim do mundo, como ele 
propõe? Estava ele certo ao anunciar o fim desse paradigma no alvorecer do novo milênio? Seria lícito associar as matrizes cristã e iluminista, como indaga o próprio Lourenço?

Em nosso entender, a resposta para a primeira pergunta é positiva. $O$ prefácio de 2000 revela que, para Eduardo Lourenço, o que tornava sua obra desatualizada 35 anos após a publicação era a impossibilidade de alcançar o fim para ela almejado, não os meios empregados para alcançar esse fim. A sua proposta de investigação, afirmava ele no primeiro prefácio que escrevera para essa obra, em 1878, configurava-se como "um discurso crítico sobre as imagens" que os portugueses já haviam forjado deles mesmos, ou seja, tratava-se de "um esboço de imagologia portuguesa" que seria "quase exclusivamente centrado sobre imagens de origem literária e em particular para a época moderna, naquelas que por uma razão ou por outra alcançaram uma espécie de estatuto mítico" (LOURENÇO, 2010, p. 18). E logo no início do texto a explicação de sua proposta nos é dada de forma lapidar: "O que é necessário é uma autêntica psicanálise do nosso comportamento global, um exame sem complacências que nos devolva ao nosso ser profundo ou para ele nos encaminhe ao arrancar-nos as máscaras que nós confundimos com o rosto verdadeiro" (LOURENÇO, 2010, p. 24).

Lourenço afirma que os portugueses confundem suas "máscaras" com "o rosto verdadeiro" (assim mesmo, com artigo determinado), o que significa não apenas que ele desvaloriza essas "máscaras", como, também, que, no seu entender, o "rosto verdadeiro" mencionado existiria e teria alguma relação de identidade com o seu "ser profundo". As "máscaras" seriam as diversas falsificações desse "rosto verdadeiro", essencial - por isso vem no singular - e conhecido - por isso é antecedido de artigo determinado. Por outro lado, Lourenço afirma ter em vista "uma autêntica psicanálise", o que também quer dizer que o "ser profundo" a que ele se refere jamais poderia ser concebido como uma unidade estável, consciente, racional. A "psicanálise mítica" que ele nos propõe configura, portanto, um encaminhamento ou uma coincidência da consciência dos portugueses vistos como um ser coletivo com a sua dimensão profunda, instável, imprevisível, irracional e inconsciente. Para Eduardo Lourenço, um tal movimento seria capaz de fazer caírem as máscaras dos 
portugueses e de levá-los a conhecerem o seu "rosto verdadeiro". São esses os pressupostos basilares d'O Labirinto da Saudade e, mais especificamente, do ensaio "Psicanálise mítica do destino português" (1978), que abre esse livro. Lourenço não invalidava esses pressupostos no prefácio de 2000, mas nos mostrava a inviabilidade de se levar a termo, na virada do milênio, essa "psicanálise mítica" que, em 1978, ele havia proposto como solução para os principais impasses da formação da identidade do povo português.

Deixemos de lado a eurocêntrica conclusão a que Eduardo Lourenço chegara ao conceber o esgotamento das duas matrizes do pensamento europeu como o fim do próprio mundo, ou como uma mudança de planeta, e partamos para a próxima indagação. É claro que aquilo que ele chama de o fim do paradigma cristão e iluminista não é o mesmo que o fim de um mundo. $\mathrm{Na}$ verdade, talvez seja possível falar em fim do paradigma cristão, mas não estamos certos de que o mesmo valha para o paradigma iluminista. Mas seria mesmo um equívoco associar a visão de mundo cristã e a visão iluminista como se ambas constituíssem um único movimento na história do pensamento ocidental. No prefácio escrito para O Labirinto em 2000, Eduardo Lourenço afirma que o mundo teria entrado em uma "idade pós-cristã". Ora, a ideia de que "o próprio Deus ele mesmo está morto" já havia sido anunciada pelo jovem Hegel, na obra Fé e Saber, em 1802. E a própria "sexta-feira santa especulativa" hegeliana amparava-se na já conhecida imagem de "um Deus perdido", expressa por Pascal em seus Pensamentos (HEGEL, 2007, p. 170-1). É Nietzsche, no entanto, quem ficaria marcado pela sentença "Deus está morto", enunciada em sua obra A gaia ciência, de 1882 (NIETZSCHE, 2001, p. 148).

O que Nietzsche chama de "morte de Deus" remete-nos à experiência fundamental do seu pensamento e representa o clímax de um processo cuja conclusão impõe a afirmação de um limite à própria história do desenvolvimento da metafísica. Para Nietzsche, a metafísica tradicional seria um saber baseado, principalmente, em dicotomias geradas a partir de um juízo de valor originário que abarcaria a existência como um todo. A dicotomia fundamental dessa forma de pensar separaria radicalmente o sensível do suprassensível numa relação em que este sempre determinaria aquele. $O$ 
suprassensível, compreendido como o conhecimento verdadeiro, seria a única realidade efetiva, enquanto o sensível, ou o devir, compreenderia o âmbito das aparências, do falso, e só alcançaria um sentido em função de sua transcendência em direção ao suprassensível. É o fracasso desse projeto metafísico que Nietzsche chama de a "morte de Deus" na história do pensamento ocidental. Trata-se, portanto, de um processo de "descristianização" iniciado com Descartes, cujo ápice se dá com a descoberta do caráter absolutamente incognoscível do mundo verdadeiro, por Kant. O que Nietzsche faz em sua filosofia é consumar, levar a termo esse processo de "descristianização", apontando para a urgência de uma transvaloração dos valores tradicionais, que encontravam na ciência de seu tempo ainda uma forma de sobrevida.

O fim do paradigma cristão, porém, não significou o fim do mundo. E não é um erro afirmar que este mundo, de certa forma, não deixa de ser herdeiro, ainda, do paradigma iluminista. O paradigma iluminista coincidiu com o cristão até determinado ponto, mas seguiu seu próprio rumo após este chegar ao fim. Ao expor todo o irracionalismo subterrâneo à vontade de verdade da ciência de seu tempo, Nietzsche não deixava de estar, também ele, a serviço do verdadeiro espírito iluminista, agindo de acordo com aquilo que o iluminismo tem de mais inalienável, que é o seu estado de crítica permanente, uma crítica que sequer poupa as próprias bases sobre as quais se ergue. Nesse sentido, a sua crítica genealógica insere-se na linha de modernidade filosófica inaugurada com o sapere aude defendido por Kant, em seu ensaio "O que é o Esclarecimento". A partir de então, a questão da modernidade passava a ser colocada em relação com 0 presente. Era ao presente que se deveria interrogar sobre as possibilidades do próprio presente. Contra todas as formas de tutela, o homem dispunha de seu próprio entendimento e era somente por meio dele que poderia sair de sua minoridade, caso tivesse coragem para servir-se de si mesmo em suas escolhas (KANT, 2005, p. 63).

É a partir desses pressupostos que pretendemos abordar o ensaio "Psicanálise mítica do destino português" (1978), de Eduardo Lourenço. O nosso objetivo é entender o significado desse texto em comparação com obras como Portugal na balança da Europa - Do que tem sido e do que ora the 
convém ser na nova ordem de coisas do mundo civilizado (1830), de Almeida Garrett, e a conferência Causas da decadência dos povos peninsulares nos últimos três séculos (1871), de Antero de Quental. Trata-se de obras que exemplificam, no contexto português, tentativas de enfrentamento das forças contrárias ao moderno movimento de emancipação de todas as tutelas que oprimem a liberdade humana.

Iniciemos com Antero, mais especificamente com o jovem Antero das Causas da decadência dos povos peninsulares, que nos parece o eco oitocentista mais sonoro no ensaio laurentino. Nessa conferência, de 1871, após estabelecer como as três causas da decadência ibérica a ortodoxia radical do catolicismo em Portugal e na Espanha, a demorada permanência desses dois países sob o absolutismo, e a desordenada espoliação humana e material que ambos impuseram às suas respectivas colônias, Antero afirma que "o futuro" dos povos peninsulares deveria ser "o novo mundo industrial do socialismo" (QUENTAL, 1987, p. 218).

Por essa época, além do idealismo de Hegel e de um socialismo mais pendente para Proudhon, Antero também andava envolvido com o "iberismo", uma tradição - ou mesmo ameaça - existente em Portugal desde que este se tornara independente, mas que somente alcançara status em parte da intelligentsia portuguesa no século XIX. O ideário iberista ganhara força com as lutas liberais ${ }^{1}$, mas apenas teria peso nas decisões políticas da época, tanto para portugueses quanto para espanhóis, após os acontecimentos que, em 1868, derrubariam a rainha D. Isabel II, de Espanha. Para o Antero que assistia a tais acontecimentos - e que publicava, nesse contexto, o artigo Portugal perante a Revolução de Espanha - Considerações sobre o futuro da política portuguesa no ponto de vista da democracia ibérica -, ainda que estas nações estivessem "postas em face de problemas diferentes", Portugal e Espanha se achavam obrigados a uma mesma solução - que, segundo ele, era a "única política possível: a da federação-republicana-democrática" (QUENTAL, 1868, p. 13). Por isso, "em face d'esta formidável unidade de interesses, de ideias, de vontades, e de aspirações", ele concluía não haver outra saída para os povos da península "senão esta: a democracia ibérica; nem outra política, política

\footnotetext{
${ }^{1}$ Em Portugal na balança da Europa, Almeida Garrett trata com seriedade desse assunto, tendo em vista suas estratégias para conquistar novos adeptos à causa liberal.
}

Pensares em Revista, São Gonçalo-RJ, n. 4, pág. 43 - 61, jan./jul. 2014 
capaz de ideias, de futuro e de grandeza, possível em Portugal, senão esta: a política do iberismo" (QUENTAL, 1868, p. 13). Antero afirmava que "não é com reformas, [...] que se sáe d'uma tal situação", pois, sendo o mal "íntimo e profundo", "a philosophia politica não [indicava] uma reforma, mas uma revolução (QUENTAL, 1868, p. 12). No seu entender, somente uma "revolução" poderia livrar os portugueses "da fórma estreita da velha nacionalidade". É de Antero:

\begin{abstract}
Se não é possivel sermos justos, fortes, nobres, intelligentes, senão deixando caír nos abysmos da historia essa coisa a que já se chamou nação portugueza, cáia a nação, mas sejamos aquillo para que nos criou a natureza, sejamos intelligentes, nobres, fortes, justos, sejamos homens, muito embora deixemos de ser portuguezes. Uma nação moribunda é uma coisa poetica: [...] Eu, por mim, pondo de parte toda a poesia e toda a sentimentalidade, contentar-me-hei de affirmar aos patriotas portuguezes esta verdade de simples bom senso: que, nas nossas actuaes circumstancias, o unico acto possivel e logico de verdadeiro patriotismo consiste em renegar a nacionalidade (QUENTAL, 1868, p. 14).
\end{abstract}

A partir dos acontecimentos de 1868, Antero passava a pensar a "revolução" no contexto do ideário iberista. Para ele, nação e revolução eram termos inconciliáveis, e ser revolucionário significava justamente ir de encontro ao nacionalismo que havia sido exacerbado pelos primeiros românticos no início de seu século, deixando para trás traumas e mitos a ele atrelados. $\mathrm{Na}$ conferência Causas da decadência dos povos peninsulares, de 1871, não é por acaso que Antero desenterra o antigo epíteto que, segundo ele, não distinguia as nacionalidades dos povos ibéricos - seriam todos "espanhóis" (QUENTAL, 1987, p. 181). Já neste trecho, por pouco não fica explícito o que havia sido afirmado enfaticamente em 68, mas que apenas é sugerido nessa conferência: "Que é pois necessário para readquirirmos o nosso lugar na civilização? Para entrarmos outra vez na comunhão da Europa culta? É necessário um esforço viril, um esforço supremo: quebrar resolutamente com o passado" (QUENTAL, 1987, p. 217).

Tanto no artigo de 68 quanto na conferência de 71 esta ideia fica clara: não havia mais ocasião para os antigos mitos, dever-se-ia celebrar o futuro, enterrando de uma vez por todas o passado decadente e calando as vozes que o cantavam. Assim, o próprio Camões - cuja estátua, mandada erigir pela Regeneração no início da década de 60, é vista por Antero, no artigo de 68, como símbolo da decadência portuguesa e objeto de consolo de sua burguesia 
estéril - aparece na conferência de 71 como um dos responsáveis pela decadência de Portugal. Num breve artigo intitulado O Romantismo e Camões, Eduardo Lourenço constata que, na leitura que Antero faz d'Os Lusíadas, esta obra não teria mais

o poder de atribuir uma identidade e uma dignidade a um país identificado com a decadência, decadência esta quase estrutural, de há três séculos, e não apenas ocasional, provocada externamente por estrangeiros, e internamente pelos inimigos da Liberdade, como no tempo de Garrett. Em última instância, Camões e seu Livro - pelo menos para Antero de Quental - podem ser englobados no processo de decadência, uma vez que o autor dos Sonetos atribui às proezas cantadas no Poema uma responsabilidade no drama de nossa decadência (LOURENÇO, 2001, p. 79).

O trecho supracitado nos diz muito sobre Antero, mas também sobre o próprio Eduardo Lourenço que se propôs a buscar a verdadeira identidade portuguesa, a "realidade nacional" que ele opõe ao "irrealismo prodigioso da imagem que os portugueses se fazem de si mesmos" (LOURENÇO, 2010, p. 23). Dessa "intrínseca e gloriosa ficção", segundo Lourenço, "Os Lusíadas são

a ficção" - ao mesmo tempo em que também seriam "o eco sumptuoso e triste", "simultaneamente sinfonia e réquiem" (LOURENÇO, 2010, p. 26). Enquanto Antero acusa o poeta épico e o seu canto de contribuírem para a decadência portuguesa, Lourenço é mais condescendente com Camões e sua obra, mas não está nisso a principal distinção entre os dois, muito menos a semelhança, como veremos.

Antero de Quental e Eduardo Lourenço se assemelham num sentido muito importante para o que aqui se quer demonstrar. Ambos constroem o edifício de sua crítica a Portugal com base numa crença, numa hipótese, de que jamais duvidam e que lhes dá a autoridade com a qual se investem para fazerem cair tudo aquilo que não pode ser reduzido por tal crença, por tal hipótese. Antero cria em certa ideia de progresso, o que o levava a questionar a abstenção portuguesa de entrar no que considerava o moderno movimento civilizador europeu, demonstrando, portanto, falta de acuidade para algumas questões sociais decorrentes desse mesmo processo de modernização - que já eram prementes em seu tempo. Eduardo Lourenço também parece se orientar por uma verdade que seria capaz de trazer luz sobre o ser português. Haveria, segundo ele, uma verdadeira identidade a ser encontrada... É o verdadeiro rosto, o rosto essencial dos portugueses que estaria escondido por 
trás de danosas máscaras, ao longo de várias gerações. Antero idealizava uma "Europa culta e civilizada" e não via as contradições que eram diariamente sufocadas no contexto real. Lourenço visa a uma dimensão profunda do ser português, onde, por meio da imagologia, seria possível encontrar a sua imagem verdadeira. Nos dois casos, é como se Portugal (no caso de Antero os povos ibéricos) fosse mesmo o único doente de um Ocidente saudável, em pleno viço, que aguardava piedosamente a convalescência lusitana.

Parecendo ter em vista a geração de Antero, Eduardo Lourenço chega à conclusão de que "em nenhum tempo do seu percurso a existência nacional foi vivida em termos tão esquizofrénicos como no século XIX" (LOURENÇO, 2010, p. 29). Curiosamente, ele vai buscar o sintoma exemplar dessa esquizofrenia numa imagem que nos é dada por Garrett e que faz referência ao período do domínio filipino, afirmando que "no centro desse percurso está simbolicamente o «ninguém» do Frei Luis de Sousa” (LOURENÇO, 2010, p. 29). A resposta dada pelo Romeiro (D. João de Portugal) ao seu antigo escudeiro, Telmo Pais, encontraria eco no fim daquele "século fantasma/ Tão sábio que [era] ateu" (QUENTAL, 2001, p. 175), como no último verso do soneto "No turbilhão", de Antero, em que um sujeito poético desesperado exclama: "Ai de mim! ai de mim! E quem sou eu?!..." (QUENTAL, 2001, p. 289); mas, sobretudo, nos dois últimos versos do soneto "Homo", também de Antero, que parece responder de forma cabal e dramática às dúvidas ontológicas finisseculares: "Sou talvez Satanás - talvez um filho/Bastardo de Jeová - talvez ninguém!" (QUENTAL, 2001, p. 275). Da crise provocada por essas dúvidas, Antero jamais conseguiria se recuperar, mas, também, jamais havia sido ou seria mais genial do que nessa fase de sua produção. Isso, porém, não é assunto para este artigo. Aqui nos interessa o Antero engajado na causa da revolução. É a ele que Eduardo Lourenço se refere quando afirma que:

O século XIX foi o século em que pela primeira vez os portugueses (alguns) puseram em causa, sob todos os planos, a sua imagem de povo com vocação autónoma tanto no ponto de vista político como cultural. Que tivéssemos merecido ser um povo, e povo com lugar no tablado universal, não se discutia. Interrogávamo-nos apenas pela boca de Antero e de parte da sua geração, para saber se éramos ainda viáveis, dada a, para eles, ofuscante decadência (LOURENÇO, 2010, p. 30).

Como bem notou Eduardo Lourenço, a discussão que tinha na boca do 
jovem Antero o verbo mais poderoso e influente centrava-se, justamente, em se saber se ainda era viável a Portugal reassumir o lugar que um dia havia ocupado no tablado universal. Discutia-se sobre a possibilidade de se alcançar um melhor lugar ao sol da civilização, sem, no entanto, se pensar no preço que deveria ser pago (e quem deveria pagar) por esse lugar privilegiado. Tanto no artigo de 68 quanto na conferência de 71. Antero não critica as regras do sistema, apenas aponta os motivos que impediam seu país de nele se posicionar de maneira competitiva. Em "Psicanálise mítica do destino português", após as suas muitas voltas sem retorno, Eduardo Lourenço não parece também ter como meta pôr em xeque as regras do sistema hegemônico em seu tempo. O problema seria a doença dos portugueses, a sua esquizofrenia multissecular, e em nenhum momento essa condição é relacionada à nova ordem que os grandes do mundo foram impondo implacavelmente aos pequenos com o rolo compressor do moderno imperialismo capitalista.

Contra um inimigo de tamanha magnitude, o "criticismo [...] da década de 70", ainda que "devastador" em certo sentido, só poderia mesmo ser visto como "impotente" (LOURENÇO, 2010, p. 31). Eduardo Lourenço assim concluiria, mais de cem anos após as históricas "Conferências do Casino". Demorou a perceber, no entanto, que também a sua "imagologia" era igualmente impotente diante desse mesmo inimigo. Faz todo sentido citar, neste momento, o Garrett das Viagens na Minha Terra, quando, em certo passo dessa obra, o "Autor" diz: "Porque, desinganem-se, o mundo sempre assim foi e há-se ser. Por mais belas teorias que se façam, por mais perfeitas constituições com que se comece, o status in status forma-se logo" (GARRETT, 2010, p. 182). O status in status a que Garrett se refere estava apenas em seu alvorecer.

Em seu ensaio, Eduardo Lourenço insiste em especular sobre o tamanho do "abismo persistente" entre a "autêntica realidade" portuguesa e "a imagem hipertrofiada" com que sempre os portugueses têm vivido a sua "vida imaginária" (LOURENÇO, 2010, p. 33). Ele reconhece que a hipertrofiada autoimagem portuguesa manteve-se a custas da barbárie, da exploração colonialista, que Antero, no início do terceiro quartel do século XIX, já havia 
visto como uma das causas da decadência de Portugal. No fundo, nenhum dos dois ataca no âmago do sistema, como fizera o jovem Garrett, em 1827, nas páginas d'O Chronista, ao analisar o que estava por detrás da economia política - exaltada por Antero em sua conferência e poupada por Lourenço em "Psicanálise mítica do destino português". Neste trecho de sua tentativa de "resumo" do que chama de o "systhema do anti-Smith francez", o economista François Louis Auguste Ferrier, Garrett afirma que o "systhema commercial nasceu da experiência, a qual fez conhecer que o interesse privado prevalece sempre sobre o interesse público, e mostra desgraçadamente os povos não somente como separados nos seus interêsses, senão como rivaes, às vezes até como inimigos" (GARRETT, 1827, p. 150). É exatamente essa a percepção que falta aos textos de Antero e de Lourenço - a ideia de que Portugal não se afundava sozinho e por livre escolha na moderna ordem econômica, que não estava indo para o fundo do poço do sistema apenas porque não soube ou não quis nele ou com ele operar, mas porque o sistema é essencialmente injusto, assim como também foi injusta a exploração colonial. Esses autores, por outro lado, propõem esforços para a inserção de Portugal na nova ordem econômica, sem mencionarem que nessa nova ordem, para que se obtenha algum sucesso, a exploração deve ser elevada à máxima potência, a uma esfera planetária, e quem sabe até interplanetária, em todo o caso, sempre desumana. Antero chega a mencionar um socialismo nas relações internas entre os povos ibéricos, mas não diz nada sobre a relação destes com os outros países. Eduardo Lourenço, por sua vez, condena o marxismo, colocando-o no mesmo saco do fascismo.

No ensaio "Psicanálise mítica do destino português", Lourenço afirma que após a Revolução de Abril "o marxismo, na sua aparência imediata, no seu vocabulário, nos seus mitos mais actuantes, não deixava grande margem para uma identificação sentimental com o nacionalismo sob nenhuma das suas formas" (LOURENÇO, 2010, p. 35). Para ele, "a Revolução descurou em excesso o sentimento nacional, deixando à futura Direita, após a cómoda hibernação que the ofereceu, a sua exaltada e frenética exploração" (LOURENÇO, 2010, p. 65). Admitindo que "os valores de «pátria», «patriotismo», «sentimento nacional» pelo seu teor afetivo, de cariz irracional, 
não costumam ser reivindicados pela Esquerda", Lourenço conclui que isso havia sido "um erro funesto", que "nenhuma Revolução triunfou com argumentos meramente ideológicos", pois "só a conjugação do interesse nacional e do interesse social assegurou o sucesso das Revoluções que triunfaram ou deixaram após elas a sua marca indelével" (LOURENÇO, 2010, p. 65). Ele prossegue sua argumentação alegando que

a ideia de Nação e o nacionalismo no seu sentido de radicação e consubstanciação com o interesse nacional, não só não são antagónicos do interesse revolucionário como lhe comunicam a sua força afectiva e a sua exigência ainda não superada por outro tipo de comunidade de mais concreta e íntima participação (LOURENÇO, 2010, p. 65).

No entender de Eduardo Lourenço, os portugueses deviam "ter encontrado num projecto nacional de vocação socialista realmente popular pela sua consubstanciação com os interesses vitais da comunidade aquilo que se perdera jogando num extremismo ideológico sem raízes fundas na tradição portuguesa". No fundo, o que ele deveras questiona é o fato de, após a Revolução de Abril, a Esquerda portuguesa não ter investido na busca de "um sentido à altura de uma Nação carregada de recordações grandiosas e cicatrizes cruéis" (LOURENÇO, 2010, p. 66). Mas tal sentido não poderia mesmo ter sido evocado por uma Esquerda de orientação materialista, antiimperialista e anticapitalista, que vive de forçar as afiadas e sujas engrenagens da toda poderosa Dialética. Ora, a Revolução que havia derrubado o fascismo não podia operar, obviamente, com os mesmos mecanismos de controle e de opressão utilizados por esse regime.

Em Portugal na balança da Europa, texto publicado em Londres, em 1830, enquanto estava em seu segundo exílio, Garrett pondera sobre a submissão de Portugal à Inglaterra e sobre os danos que tal postura ante a potência insular poderia trazer ao seu país. ${ }^{2}$ De forma paradoxal, ele apresentava como única alternativa restante a Portugal "para podêr existir em harmonia com o novo princípio europeu; mais simplesmente e mais

\footnotetext{
${ }^{2}$ Garrett refere-se, sobretudo, aos perigos que essa submissão representava à independência de Portugal, já que, segundo o fragmento de ensaio que ele insere no texto em questão, o hábito da subserviência e o afrouxamento do sentimento de nacionalidade resultante desse hábito fatalmente faria com que Portugal se entregasse, sem resistências, "À Hespanha [ , ] sempre de güella aberta para engulir uma preza que incessante persegue" (GARRETT, 1830, p. 286); unindo-se, "como província á mesma potência cujo mais teimoso e irreconciliável inimigo foi enquanto Estado independente" (GARRETT, 1830, p. 284-285).
} 
absolutamente, para podêr existir": "ou continuar a ser potência independente mais independente devéras, ou voltar a ser província de Hespanha" (GARRETT, 1830, p. 282).

Nesse texto, Garrett investe poderosos argumentos no desenvolvimento do primeiro "membro" do paradoxo por ele apresentado: a tese da "independência verdadeira, isto é, independência com liberdade, com instituições que a segurem" (GARRETT, 1830, p. 289); afirmando que essa "independência com liberdade" apenas se concretizaria "com instituições prudentes e justas" que reunissem "a conveniência das fórmas com a solidez e legalidade dos princípios" (GARRETT, 1830, p. 291). Ele argumenta que "Nenhum pacto social póde ser fundado senão na liberdade natural do homem e em sua igualdade legal", e que "nenhum código político póde ser bem formado se não garantir o exercício d'aquela e a conservação d'esta" (GARRETT, 1830, p. 292), concluindo que "o modo porque essa garantia se ha de estabelecer depende das circunstâncias de cada paiz" (GARRETT, 1830, p. 292-3).

Somente após investir naquilo que considerava questão de vida e de morte: "Todos daremos o derradeiro sangue pela independência nacional" (GARRETT, 1830, p. 319); é num acesso de ímpeto e de brio muito parecido com o do personagem de sua obra Frei Luís de Sousa, Manuel de Sousa Coutinho, quando este ateia fogo à própria casa para não vê-la habitada pelos representantes do governo filipino, que Garrett dá o que aparentemente seria a sua última cartada nesse texto, afirmando: "Portugal só poderá ir unir-se a Hespanha por uma espécie de vingança ou ressentimento contra a injustiça, tyrania e insultos de Inglaterra" (GARRETT, 1830, p. 287). Antes, porém, de virar a última carta, Garrett ainda afirmaria, num ao mesmo tempo magistral e dramático blefe: "Mas a esperança, a querida esperança que ainda nutrimos e affagâmos, de que não seremos constrangidos a essa extremidade, me arreda a Penna do repugnante assumpto". Para que não ficassem dúvidas sobre a sua posição naquele momento, ele concluía: "Preza a Deus que não seja necessário volver a elle!" (GARRETT, 1830, p. 319-20).

Garrett dá, enfim, a cartada anunciada. Porém, em vez de assumir uma atitude de resignação e sacrifício, ele tirava outra carta da manga: "Mas se o 
for, [...] façamo-lo com dignidade e prudência" (GARRETT, 1830, p. 320), pois "viria naturalmente o tractar do modo e condições com que a união deve ser feita para que menos pesada e mais vantajosa nos seja" (GARRETT, 1830. p. 319).

Como o Garrett de Portugal na balança da Europa, Manuel de Sousa Coutinho agiria com "dignidade", ao desfazer-se da própria casa para não vê-la no gozo dos inimigos; mas, também, com "prudência", ao assegurar-se dos cuidados necessários para que ninguém saísse ferido, e ao negociar, usando de suas influências, uma espécie de salvo-conduto que 0 isentaria de retaliações por parte das autoridades ofendidas. Sem falar no fato de que o personagem já tinha em mente o novo destino para onde levaria a família: a antiga casa em que haviam vivido Dona Madalena de Vilhena, sua esposa, e Dom João de Portugal, o antigo esposo desta, que se pensava estar morto. De certa forma, estava tudo calculado, menos o regresso do dono da casa - o Garrett da década de 40 já sabia que não tínhamos a vida nas mãos.

A posição real do jovem Garrett ante a melhor decisão a ser tomada na conjuntura política em que se encontrava Portugal fica, portanto, muito clara quando ele diz: "calculemos todas as possibilidades dos meios que nos restam para conservar nossa preciosa independência" (GARRETT, 1830, p. 291). Ofélia Paiva Monteiro, em seu livro Estudos Garrettianos, ressaltando o fato de Garrett - "ele, tão profundamente nacionalista!" - ter admitido "o horror de uma união com Espanha, se tanto fosse preciso para vencer o 'despotismo"' (MONTEIRO, 2010, p. 90), destaca, também, o "cunho vincadamente historicista e pragmático" de Portugal na balança da Europa, obra em que, segundo ela, Garrett "defende o liberalismo moderado da Carta, equacionando a situação portuguesa e o passado recente nacional à luz de critérios de visibilidade e de conveniência, lucidamente atentos ao contexto europeu e americano" (MONTEIRO, 2010, p. 86-7).

Confirmando essa atenção lúcida ao contexto europeu e americano, que Ofélia Paiva Monteiro atribui ao autor de Portugal na balança da Europa, o jovem Garrett, pensando na forma mais vantajosa para que Portugal aceitasse a "repugnante" união com a Espanha, propõe: "Talvez uma federação... Mas suspendamos por ora todas as reflexões sobre este objecto" (GARRETT, 1830, 
p. 320). Não estamos certos quanto ao fato de Garrett saber ou não o que era isto, mas a estrutura enunciativa de seu texto em tudo nos faz lembrar um blefe, com toda a conotação dramática que o caracteriza.

Apesar dos cuidados tomados, o fato é que, para conquistar adeptos à causa liberal, o Garrett de 1830, guiado ainda por uma ideia absoluta de Liberdade, punha a própria soberania da pátria na roda de jogo - pelo menos no plano da hipótese. O jovem Antero, tendo os olhos voltados para os modelos político-econômicos da Inglaterra, da França e dos Estados Unidos, propunha, em sua conferência, um virar de página absoluto na história da nação portuguesa. O Eduardo Lourenço de "Psicanálise mítica do destino português" questiona o antitradicionalismo avassalador da Revolução, por esta ter feito da tradição uma espécie de tábua rasa após derrubar um regime que, por mais de quatro décadas, havia utilizado os valores tradicionais de patriotismo e de nacionalismo como elementos de controle e de alienação popular.

Como temos tentado pontuar ao longo deste artigo, nosso objetivo não é o de dar a palavra final sobre a obra integral desses três autores. Os especialistas sabem que, ao se falar de Garrett, de Antero, é necessário delinear bem precisamente o objeto de estudo, mostrar, de forma cuidadosa, de que Garrett e de que Antero se fala. Trata-se de autores que nunca se cristalizaram intelectualmente. É claro que há continuidades, interpenetrações, mas, sobretudo, fases, que demarcam bem em que medida antigas ideias prevalecem e em que medida novas ideias vão surgindo. Com Eduardo Lourenço parece-nos ocorrer algo parecido. O próprio fato de iniciarmos nossas considerações neste artigo sobre o ensaio "Psicanálise mítica do destino português" (1978), tendo como referência o prefácio que, desde 2000, abre a obra O labirinto da Saudade - de que faz parte o ensaio abordado -, é revelador da atenção que demos às revisões que o seu autor fizera nas teses lançadas nesse texto. Foram justamente essas revisões que nos deram a ideia de comparar esse ensaio com outras obras congêneres, também capitais para a entrada de Portugal no moderno movimento do pensamento ocidental. Talvez fosse possível acrescentar outros nomes, outras obras, à comparação que empreendemos. Com certeza essa comparação poderia ter sido mais profunda, 
mais paciente, mais erudita. Nossa contribuição é apenas um ensaio.

Em nosso artigo, tentamos demonstrar que Garrett, Antero e Eduardo Lourenço contribuíram - no caso do último temos a felicidade de poder dizer que tem contribuído - para entrada de Portugal no moderno movimento do pensamento ocidental. E o que tem sido esse movimento? Trata-se de um movimento que busca, às vezes contra si mesmo, levar o gênero humano a mais completa liberdade possível. Esse movimento venceu uma primeira batalha contra o absolutismo, contra os chamados inimigos da Liberdade, mas depois teve de se entender consigo mesmo. Ideias como nação e revolução foram e ainda são capitais nesse processo. Revoluções têm sido suscitadas para defender a soberania da pátria, da nação, e revoluções têm sido igualmente suscitadas com o objetivo inverso, o de levar essas entidades à derrocada. O que há em comuns aos dois acontecimentos? A busca pela liberdade, podemos arriscar. É por essa busca que Garrett põe em risco a nação que ele tanto demonstrou amar. É por essa busca que Antero pretendeu dissolver a mesma nação, por concluir que a mesma havia se tornado inútil. $O$ autor d'O Labirinto da Saudade viveu um tempo em que as ideias de pátria e de nação haviam sido utilizadas em nome da opressão fascista. Era necessária a revolução para derrubar esse regime. Ela veio, mas trouxe consigo o fantasma do excesso de confiança na ideologia. É claro que não há mais cabimento em se revestir as ideias de pátria e de nação com o caráter mitológico que elas adquiriram no romantismo. Essas ideias devem ser racionalmente concebidas e sem complacências criticadas. Os três autores aqui abordados buscaram isso em seus textos, por meios distintos, estratégias precisamente calculadas, de acordo com o contexto vivenciado. Com isso, eles relativizaram mesmo o conceito de revolução. $O$ modo como se é revolucionário depende das circunstâncias. Neste artigo, pretendemos, portanto, demonstrar exatamente sob quais circunstâncias é possível afirmar que os três autores aqui abordados foram revolucionários nos textos por nós cotejados. 


\section{Referências bibliográficas}

CATROGA, Fernando. Antero de Quental: história, socialismo, política. Lisboa: Editorial Notícias, 2001.

DAVID, Sérgio Nazar. Almeida Garrett: sua Viagem, sua Vertigem. In: Paixão e Revolução. Rio de Janeiro: EdUERJ, 1996.

GARRETT, Almeida. Frei Luis de Sousa. [s.I.]: Edições de Ouro, [s.d.].

O chronista - Semanário de política, literatura, sciencias e artes. Lisboa: Imprensa do Portuguez, 1827.

Portugal na balança da Europa: do que tem sido e do que ora the convem ser na nova ordem de coisas do mundo civilizado. Londres: S. W. Sustenance, 1830.

. Viagens na minha Terra. Edição crítica. Ed. Ofélia Paiva Monteiro. Lisboa: Imprensa Nacional-Casa da Moeda, 2010.

HEGEL. Fé e saber. 2 ed. São Paulo: Hedra, 2011.

KANT, Immanuel. Textos seletos. Petrópolis: Vozes, 2005.

LOURENÇO, Eduardo. O labirinto da saudade - Psicanálise mítica do destino português. 7 ed. Lisboa: Gradiva, 2010.

O Romantismo e Camões. In.: Idioma, 21. Rio de Janeiro: Centro Filológico Clóvis Monteiro - UERJ, 2001.

MONTEIRO, O. P. Estudos garretianos. Rio de Janeiro: Eduerj, 2010.

NIETZSCHE, Friedrich Wilhelm. A gaia ciência. São Paulo: Companhia das letras, 2001.

QUENTAL, Antero de. Antero de Quental: Textos doutrinários e correspondência. [S.I.]: Círculo de Leitores, 1987. v. 1.

2001.

Poesia completa: 1842-1891. Lisboa: Publicações Dom Quixote,

. Portugal perante a revolução de Espanha. Considerações sobre o futuro da política portuguesa no ponto de vista da democracia ibérica.

Pensares em Revista, São Gonçalo-RJ, n. 4, pág. 43 - 61, jan./jul. 2014 
Lisboa: Typographia Portugueza, 1868.

ROUANET, Sérgio Paulo. As razões do Iluminismo. São Paulo: Companhia das Letras, 1987.

TARNAS, Richard. A epopeia do pensamento ocidental: Para compreender as ideias que moldaram nossa visão de mundo. Rio de Janeiro: Betrand Brasil, 2008. 
Artigo recebido em: 11 de julho de 2014

Artigo aprovado em: 19 de setembro de 2014

\section{Sobre o autor:}

Silvio Cesar dos Santos Alves possui Doutorado em Literatura Comparada e Mestrado em Literatura Portuguesa pela UERJ. É autor da Tese Os paradoxos do niilismo em Antero de Quental, Eça de Queirós e Cesário Verde (2013), e da Dissertação Repensando o São Cristóvão no conjunto da obra queirosiana (2008). Em 2009, participou como conferencista no Colóquio Internacional "Os Estudos queirosianos - desafios actuais", realizado pela Fundação Eça de Queiroz e pela Universidade do Porto, apresentando a conferência "Repensando o 'São Cristóvão' no conjunto da obra queirosiana", publicada no n.- 21/22 da Revista Queirosiana - Estudos sobre Eça de Queirós e sua Geração, de 2014. Faz parte do Polo de Pesquisa sobre Relações LusoBrasileiras (PPRLB) - vinculado ao Centro de Estudos do Real Gabinete Português de Leitura - e do Grupo Eça - vinculado ao Departamento de Letras Clássicas e Vernáculas da USP. Atualmente, desenvolve pesquisa de PósDoutorado no Programa de Pós-Graduação em Letras da UERJ, investigando as poéticas portuguesas finisseculares e primonovecentistas. Possui vínculo profissional com a Fundação de Apoio à Escola Técnica do Estado do Rio de Janeiro (FAETEC/RJ), atuando como professor nas disciplinas de Língua Portuguesa, Literatura e Produção Oral e Escrita. Em 2013, obteve a $1^{\text {a }}$ colocação no concurso de provas e títulos para o cargo de Professor Adjunto de Literatura Portuguesa da Universidade Estadual de Londrina (UEL). 